\title{
Villus height and gut development in weaned piglets receiving diets containing either glucose, lactose or starch
}

\author{
M. A. M. Vente-Spreeuwenberg ${ }^{1 *}$,J. M. A. J. Verdonk ${ }^{2}$, M. W. A. Verstegen ${ }^{3}$ and A. C. Beynen ${ }^{4}$ \\ ${ }^{1}$ Swine Research Centre, Nutreco, PO Box 240, 5830 AE Boxmeer, The Netherlands \\ ${ }^{2}$ ID TNO Animal Nutrition, PO Box 65, 8200 AB Lelystad, The Netherlands \\ ${ }^{3}$ Division of Animal Nutrition, Department of Animal Sciences, University of Wageningen, Wageningen, \\ PO Box 338, $6700 \mathrm{AH}$ Wageningen, The Netherlands \\ ${ }^{4}$ Department of Nutrition, Faculty of Veterinary Medicine, Utrecht University, PO Box 80.152, 3508 TD Utrecht, \\ The Netherlands
}

(Received 4 November 2002 - Revised 3 July 2003 - Accepted 28 July 2003)

\begin{abstract}
The present study was designed to evaluate the differential effects of dietary glucose, lactose and starch on small-intestinal morphology, organ weights, $\mathrm{pH}$ of chyme and haptoglobin levels in blood plasma of weaned piglets. It was hypothesised that lactose consumption would ameliorate the weaning-induced decrease in gut integrity. A total of forty-two barrows were used. Piglets were weaned at 27 (SD 0.8) $\mathrm{d}$ of age and weighed 8.0 (SD 0.51) kg. On the day before weaning (day -1) all pigs were blocked according to body weight and randomly assigned to seven groups (n 6 per group). The groups differed in diet and day of dissection. On the day of weaning, dissection was performed on one group of six piglets. The remaining groups were fed one of three experimental diets in which glucose, lactose or starch had been iso-energetically exchanged, supplying $24 \%$ dietary energy. The piglets received a liquid diet (air-dry meal:water of $1: 2, \mathrm{w} / \mathrm{w})$. The piglets were given access to a maximum of dietary energy in order to prevent confounding between feed intake and villus architecture. The piglets were dissected and sampled on days 0,3 , or 10 post-weaning. The results show that the carbohydrate source did not affect growth performance, organ weights, villus architecture, $\mathrm{pH}$ of chyme and plasma haptoglobin level. The weaning transition resulted in decreased villus height and increased haptoglobin levels. In the contents of the caecum and large intestine, the $\mathrm{pH}$ decreased after weaning. It is concluded that at least under conditions of similar feed intake and low infectious pressure, dietary lactose does not ameliorate the weaning-induced compromise of small-intestinal integrity when compared with either glucose or starch.
\end{abstract}

Weaned piglets: Carbohydrate source: Gut morphology

At weaning, the diet composition of piglets changes drastically. The liquid sows' milk is replaced by pelleted dry feed with carbohydrates, instead of fat, as the main energy source. In addition, lactose, the main carbohydrate in milk, is replaced by starch. The weaning transition is accompanied by low feed intake (Leibbrandt et al. 1975; Okai et al. 1976), which causes a reduction in villus height (Kelly et al. 1991; Pluske et al. 1996; Verdonk et al. 2001a).

Epithelial cells need energy to maintain gut integrity. Glucose is an energy source for epithelial cells (Mallet et al. 1986). By providing glucose as a preferred energy source for the epithelial cells, the effect of post-weaning low feed intake on small-intestinal architecture might be ameliorated. However lactose is one of the main constituents of sows' milk (Darragh \& Moughan, 1998) and is cleaved by lactase in the brush-border membrane, such that glucose and galactose are absorbed into the enterocytes. Additionally, it has been shown that increasing the amounts of lactose in the weaner diet at the expense of protein is associated with higher group-mean villus height in the proximal small intestine of piglets (Spreeuwenberg et al. 2001). It can be hypothesised that lactose, being the main sugar in sows' milk, has specific properties contributing to mucosal integrity in newly weaned piglets. To test the specificity of lactose, three experimental weaner diets were formulated containing $24 \%$ of total net energy in the form of glucose, lactose or starch. The diets were supplied to weanling piglets and their villus height and crypt depth were measured on 3 and $10 \mathrm{~d}$ post-weaning.

\section{Materials and methods}

Piglets and weaning

Barrows ( $n$ 42) used were from the Swine Research Centre of Nutreco: (Duroc $\times$ Yorkshire synthetic $) \times($ Yorkshire $\times$ Dutch Landrace synthetic). The piglets were weaned at

\footnotetext{
Abbreviations: BW, body weight; $\mathrm{Hp}$, haptoglobin; $\mathrm{NE}_{\mathrm{m}}$, net energy for maintenance.

Presented in part in abstract form (Spreeuwenberg et al. 2002).

* Corresponding author: Dr M. A. M. Vente-Spreeuwenberg, fax +31 485 577311, email mirjam.vente@nutreco.com
} 
27 (SD 0.8) d of age (day 0) and weighed 8.0 (SD 0.51) kg. Creep feed was not provided during the suckling period so as to enhance the differential response, if any, to the experimental diets and to prevent the induction of inter-individual variability by variable pre-weaning ingestion of solid feed (Bruininx, 2002). At weaning, the pigs were removed from the sow, weighed and housed individually in pens $\left(80 \times 100 \mathrm{~cm}^{2}\right)$. Each pen was equipped with two feed troughs and a nipple drinker. The environmental temperature was maintained at $27^{\circ} \mathrm{C}$. During the day of weaning, lights were on continuously. From day 1 onwards lights were on from 06.00 until 22.00 hours. The experimental protocol was approved by the Animal Care and Ethics Committee of the University of Nijmegen (The Netherlands).

\section{Feeds, feeding and experimental design}

On the day before weaning (day -1 ), the piglets were weighed and placed back with the sow. Based on those weights the piglets were blocked by body weight (BW) and randomly allocated to one of seven groups. In total, piglets of seventeen litters were used; littermates were evenly distributed among dietary treatment and among day of dissection. On the day of weaning (day 0), dissection was performed on a group of six piglets. The remaining six groups were dissected on day 3 or 10 postweaning and received one of the three experimental diets in the form of a slurry. The water:air-dry feed value was $2: 1(\mathrm{w} / \mathrm{w})$.

The experimental diets differed in their carbohydrate composition. A mixture of constant components was formulated (Table 1). Glucose, lactose and wheat starch were isoenergetically exchanged and supplied $24 \%$ of the total energy of the diet. Wheat starch is regarded as rapidly digestible based on its in vitro, fractional digestion rate and has a total potential digestibility of 99.9 (SD 0.93)

Table 1. Ingredient composition of the experimental diets

\begin{tabular}{lccc}
\hline Dietary variable & Glucose & Lactose & Starch \\
\hline Constant components* $(\mathrm{g})$ & 800.0 & 800.0 & $800 \cdot 0$ \\
Glucose $(\mathrm{g})$ & 213.8 & - & - \\
Lactose $\neq(\mathrm{g})$ & - & 200.0 & - \\
Native wheat starch§ $(\mathrm{g})$ & - & - & 203.9 \\
Total $(\mathrm{g})$ & 1013.8 & 1000.0 & 1003.9 \\
\hline
\end{tabular}

* The constant components consisted of ( $\mathrm{g} / 800 \mathrm{~g}$ feed): wheat, 464.8 ; wheat bran, 120.0; wheat gluten, 24.8; soyabean concentrate, 80.0 ; potato protein, 24.0; fishmeal, 40.0; soyabean oil, 20.1; limestone, 9.1; monocalcium phosphate, 3.3; fytase liquid, 0.08; choline chloride (purity $50 \%$ ), 0.64; salt, 5.4; methionine, 1.2; lysine, 3.3; tryptophan, 0.64; threonine, 1.2; vitamin and trace element premix, 1.6. The vitamin and trace element inclusion supplied (per $800 \mathrm{~g}$ constant components): vitamin A, $8000 \mathrm{IU}$; $\left(2.752 \mathrm{mg}\right.$ retinyl acetate) vitamin $D_{3} 0.04 \mathrm{mg}, 1600 \mathrm{IU}$; vitamin $\mathrm{E}, 52000$ IU $52 \mathrm{~g}$ (DL-alfa-tocophenyl-acetate); vitamin $\mathrm{K}_{3}, 1.6 \mathrm{mg}$; vitamin $\mathrm{B}_{1}$, $0.8 \mathrm{mg}$; vitamin $B_{2}, 2.4 \mathrm{mg}$; pantothenic acid, $8.0 \mathrm{mg}$; niacin, $16.0 \mathrm{mg}$; biotin, 24.0 $\mu \mathrm{g}$; vitamin $B_{12}, 16.0 \mu \mathrm{g}$; folic acid, $0.16 \mathrm{mg}$; vitamin $B_{6}, 3.2 \mathrm{mg}$; $\mathrm{Fe}, 128.0 \mathrm{mg} ; \mathrm{Cu}, 128.0 \mathrm{mg} ; \mathrm{Zn}, 80.0 \mathrm{mg} ; \mathrm{Mn}, 24.0 \mathrm{mg} ; \mathrm{I}, 8.0 \mathrm{mg} ; \mathrm{Se}$, $0.16 \mathrm{mg}$; antioxidants (E130, E320, E321), $48.0 \mathrm{mg}$.

†C-Dex (Cerestar, Sas van Gent, The Netherlands); DM content, 91.4\%; dextrose, $92.29 \%$

‡Lactopure (Borculo Domo Ingredients, Zwolle, The Netherlands); DM content, $99.9 \%$; lactose, $94.20 \%$.

$\S$ Cerestar PT 20002 (Cerestar, Sas van Gent, The Netherlands); DM content, $88.3 \%$; starch, $86.50 \%$.
$\%$ (Weurding et al. 2001). The calculated nutrient composition of the experimental diets is shown in Table 2 .

After weaning (days 0 to 10), the piglets were given access to a maximum amount of dietary energy. The following formula describes the amount of net energy for maintenance $\left(\mathrm{NE}_{\mathrm{m}}\right)$ of the piglets according to their metabolic weight on the day of weaning $\left(\mathrm{BW}_{0}^{0.75}\right.$ ) (National Research Council, 1998):

$$
\mathrm{NE}_{\mathrm{m}}(\mathrm{kJ} / \mathrm{d})=326.4 \times \mathrm{BW}_{0}^{0.75}
$$

where $\mathrm{NE}_{\mathrm{m}}$ is the net energy intake at maintenance level $(\mathrm{kJ} / \mathrm{d})$ and $\mathrm{BW}_{0}$ is $\mathrm{BW}$ on day $0(\mathrm{~kg})$. The piglets were offered $0.5 \times \mathrm{NE}_{\mathrm{m}}$ on day $0,0.75 \times \mathrm{NE}_{\mathrm{m}}$ on day 1 , $1.0 \times \mathrm{NE}_{\mathrm{m}}$ on day $2,1.5 \times \mathrm{NE}_{\mathrm{m}}$ on day 3 and $2.0 \times \mathrm{NE}_{\mathrm{m}}$ from day 4 onwards. The piglets were fed equal portions of feed three times/d from day 0 to 3 (at $10.00,13.00$ and 16.00 hours) and two times/d from day 4 onwards (at 10.00 and 16.00 hours). Feed refusals were collected, weighed and dried overnight at $100^{\circ} \mathrm{C}$. Actual daily DM intake (g) and net energy intake $/ \mathrm{kg}$ metabolic weight were calculated $\left(\mathrm{kJ} / \mathrm{kg} \mathrm{BW}{ }_{0}^{0.75}\right)$.

\section{Growth performance and faeces consistency}

The piglets were weighed on days $-1,0,3$ and 10 postweaning. Average daily gain was calculated for the periods -1 to 0,0 to 3 and 3 to $10 \mathrm{~d}$. Faecal consistency was monitored twice per $\mathrm{d}$ and quantified using a score on a scale from 0 to 3 , with 0 being normally shaped faeces, 1 being shapeless (loose) faeces, 2 being thick, liquid (soft) faeces, and 3 being thin, liquid faeces (watery diarrhoea). The scoring was done by experienced care-takers who were unaware of piglet treatment.

\section{Sampling}

On days 0,3 and 10 post-weaning, the piglets to be killed were weighed and killed with a $5 \mathrm{ml}$ intra-cardiac injection of Euthestate ${ }^{\circledR}$ (pentobarbital sodium $200 \mathrm{mg} / \mathrm{ml}$;

Table 2. Calculated nutrient composition of the experimental diets $(\mathrm{g} / \mathrm{kg})^{\star}$

\begin{tabular}{lccc}
\hline & Glucose & Lactose & Starch \\
\hline DM & 894 & 910 & 887 \\
Crude protein & 194 & 197 & 196 \\
Fat & 36 & 37 & 36 \\
Crude fibre & 24 & 25 & 25 \\
Ash & 42 & 42 & 43 \\
Total carbohydrates $\dagger$ & 598 & 609 & 587 \\
Total sugars & 215 & 20 & 20 \\
Lactose & 0 & 188 & 0 \\
Starch & 311 & 315 & 490 \\
Net energy (MJ/kg) $\ddagger$ & 10.21 & $10 \cdot 07$ & $10 \cdot 17$ \\
\end{tabular}

* Minerals and vitamins were (per kg feed): $\mathrm{Ca}, 5.9 \mathrm{~g} ; \mathrm{P}, 5.2 \mathrm{~g}$; Na, $2.9 \mathrm{~g} ; \mathrm{K}, 6.3 \mathrm{~g} ; \mathrm{Cl}, 5.7 \mathrm{~g}$; Cu, $131.2 \mathrm{mg}$; vitamin E, 51.7 IE. Apparently ileal digestible amino acids were $(\mathrm{g} / \mathrm{kg}$ feed): lysine, 10.7 ; methionine, 4.2; methionine + cystine, 6.7 ; threonine, 6.8 ; tryptophan, 2.5 .

†Calculated as: DM - (crude protein + fat + crude fibre + ash).

$\ddagger$ Calculated with the use of the Dutch feed tables (Centraal Veevoederbureau, 2000). 
Ceva Sante Animale B.V., Maasluis, The Netherlands). A midline laparotomy was performed. From the vena cava caudalis a blood sample was taken into a $9 \mathrm{ml}$ tube with heparin (Lithium-Heparin-Monovette ${ }^{\circledR}$; Sarstedt, Nümbrecht, Germany). After mixing carefully, the tubes were immediately put on ice and then centrifuged (10 min, $1100 \mathrm{~g})$. Plasma was stored in the freezer $\left(-20^{\circ} \mathrm{C}\right)$ until analysis. A jejunal segment was taken at $0.5 \mathrm{~m}$ distal to the ligament of Treitz (proximal jejunum) and a second segment at $3.5 \mathrm{~m}$ distal of this ligament (mid-jejunum). A sample of approximately $100 \mathrm{~mm}$ was taken from the proximal jejunum and the length and width were measured. Of this sample the mucosal layer was carefully scraped off from the muscle layer with an object-glass and weighed. The mucosal weight was expressed per $\mathrm{cm}^{2}$. The liver and pancreas were removed and weighed. The small intestine was divided into three parts: the first $2 \mathrm{~m}$ distal of stomach (proximal small intestine); the last $2 \mathrm{~m}$ proximal of the caecal valve (distal small intestine); the middle, remaining part (mid-small intestine). Chyme was collected and mixed, $\mathrm{pH}$ was measured and empty weight was determined of the stomach, proximal, mid- and distal small intestine, caecum and large intestine. Empty BW was determined as animal weight without the gastrointestinal tract, liver and spleen.

For histological analysis, tissue samples $(20 \mathrm{~mm})$ of the proximal and mid-jejunum were cut open longitudinally at the anti-mesenteric attachment, fixed onto dental wax with the villi on the upper side and put in phosphate-buffered formalin solution $(0.1 \mathrm{~mol} / \mathrm{l} ; 40 \mathrm{ml}$ formalin/l). A $3 \mathrm{~mm}$ wide zone from the mesenteric site was cut at right angles to the surface of the mucosa and embedded in paraffin wax. Sections $(5 \mu \mathrm{m})$ were cut and stained with the periodic acid-Schiff procedure. These periodic acidSchiff-stained sections were subsequently used to determine crypt depth $(\mu \mathrm{m})$ and villus length $(\mu \mathrm{m})$. One slide per piglet was used and the average values taken for a minimum of five villi and crypts.

Total antibody titres to haptoglobin (Hp) in plasma were determined by ELISA (Biofocus GmbH, Recklinghausen, Germany) as described (Hiss, 2001; Hiss et al. 2001). Briefly, biotinylated porcine Hp was used as a tracer and was incubated together with either an $\mathrm{Hp}$ standard or plasma in microtitre plates coated with sheep anti-rabbit crystalline-fragment immunoglobulins. After adding the specific rabbit antiserum, plates were incubated for $1 \mathrm{~h}$, washed and evaluated via a streptavidin peroxidase system with tetramethylbenzidin as substrate. Hp levels are expressed as $\mathrm{mg} / \mathrm{ml}$ plasma.

\section{Statistical analysis}

A general linear model procedure (SAS version 6.12; SAS Institute, Cary, NC, USA) was used to estimate the leastsquare means of the different variables. The effect of diet composition was evaluated within the $3 \times 2$ experimental design with three experimental diets and days 3 and 10 as dissection days:

$$
y_{i j k}=\mu+D_{i}+C_{j}+(D \times C)_{i j}+e_{i j k},
$$

where $y_{i j k}$ is the dependent variable; $\mu$ is the overall mean; $D_{i}$ is the fixed effect of day of dissection $(i=1,2) ; C_{j}$ is the fixed effect of diet composition $(\mathrm{j}=1,2,3)$; $(\mathrm{D} \times \mathrm{C})_{\mathrm{ij}}$ is the interaction between day of dissection and diet composition; $\mathrm{e}_{\mathrm{ijk}}$ is the error term.

The effect of day post-weaning was evaluated across diets with day post-weaning as the only independent variable:

$$
\mathrm{y}_{\mathrm{ij}}=\mu+\mathrm{D}_{\mathrm{i}}+\mathrm{e}_{\mathrm{ij}},
$$

where $y_{i j}$ is the dependent variable; $\mu$ is the overall mean; $D_{i}$ is the fixed effect of day of dissection $(i=1$, $2,3)$; $\mathrm{e}_{\mathrm{ij}}$ is the error term.

To compare the effect of a specific diet on day 3 or 10 with the day of weaning, the seven groups were regarded as different treatments:

$$
\mathrm{y}_{\mathrm{ij}}=\mu+\mathrm{T}_{\mathrm{i}}+\mathrm{e}_{\mathrm{ij}},
$$

where $y_{i j}$ is the dependent variable; $\mu$ is the overall mean; $\mathrm{T}_{\mathrm{i}}$ is the fixed effect of treatment $(\mathrm{i}=1,2, \ldots, 7)$. The experimental groups differing in diet and day of dissection were regarded as different treatments; $\mathrm{e}_{\mathrm{ij}}$ is the error term. Only pre-planned comparisons were made, i.e. between diets within either day 3 or 10 and between days (day 0 , 3 and 10) for the same diet.

The repeated measures option of the general linear model procedure was used to analyse differences between $\mathrm{pH}$ in the different parts of the gastrointestinal tract. The incidence of faeces inconsistency was not distributed normally. Therefore, the effect of dietary treatment on faeces inconsistency was analysed by $\chi^{2}$ analysis of the Cadmod procedure. Pearson correlation analysis was performed to evaluate selected correlations. For all data combined, feed intake as a function of days post-weaning was plotted in the form of a box-whisker graph and as means. Significance was assigned at $P<0.05$; tendencies were assigned at $0 \cdot 05<P<0 \cdot 10$.

\section{Results}

None of the piglets showed signs of illness. Energy intake and average daily gain did not differ between dietary treatments. Daily feed intake $\left(\mathrm{kJ} / \mathrm{kg} \mathrm{BW}^{0.75}\right.$ per pig) across dietary treatments is shown in Fig. 1 as a box-whisker plot. There was substantial inter-individual variation in feed intake. On average, the energy intake required for maintenance was reached on day 4 post-weaning. For all piglets combined, the average daily DM intake was 59 (SD 58.6) $\mathrm{g} / \mathrm{d}$ per pig during the first $3 \mathrm{~d}, 122$ (SD 49.2) g/d per pig during the first week and 163 (SD 39.9) g/d per pig during the entire $10 \mathrm{~d}$ period. Daily feed intakes during the first $3 \mathrm{~d}$ post-weaning did not differ between the piglets dissected on day 3 or 10 . The average daily gain was 281 (SD 145.2) $\mathrm{g}$ from days -1 to $0(n 42),-40$ (SD 96.2) $\mathrm{g}$ from days 0 to 3 ( $n$ 36), 202 (SD 58.9) $\mathrm{g}$ from days 3 to $10(n$ 18) and 128 (SD 61.6) $\mathrm{g}$ from days 0 to 10 . Feed intake and growth were positively correlated $(P<0 \cdot 01)$.

The percentage of days that a piglet had non-consistent faeces (i.e. score 1, 2, or 3) did not differ between dietary treatments $(P>0 \cdot 10)$ and for all piglets combined was 


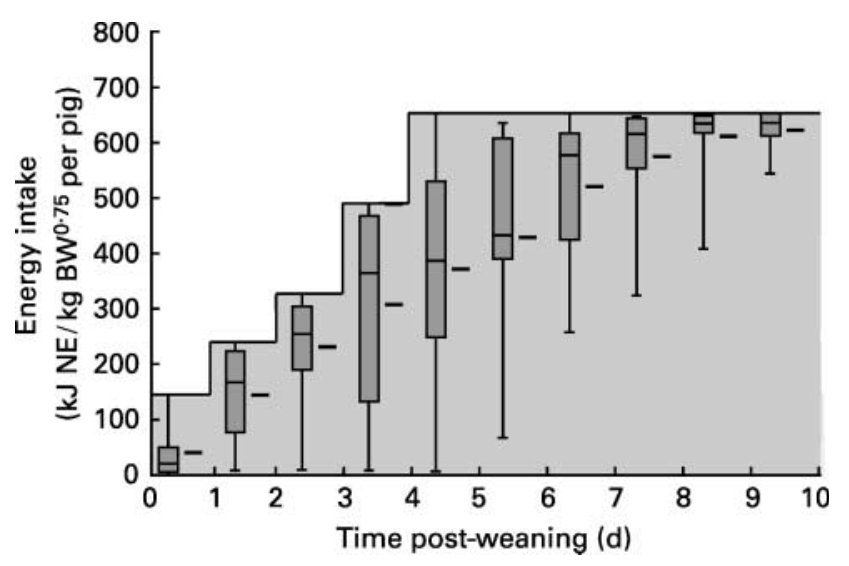

Fig. 1. Box-whisker graph of the daily energy intake of piglets, for the first $10 \mathrm{~d}$ after weaning, expressed as $\mathrm{kJ}$ net energy (NE)/kg metabolic weight (BW ${ }^{0.75}$; days $1-3, n$ 36; days $4-10, n$ 18). The graph shows the medians within the boxes and the means as adjacent bars. The upper and lower closures of the boxes indicate the quartiles, and the vertical lines (whiskers) represent the ranges. The grey area represents the amount of feed offered. The amount of feed needed for maintenance/pig is $326.4 \mathrm{~kJ} \mathrm{NE} / \mathrm{kg} \mathrm{BW} \mathrm{BW}^{0.75}$ per d.

8 (SD 18.5$) \%$ from days 0 to 3 and 16 (SD 15.8$) \%$ from days 0 to 10 . For the piglets dissected on day 10 this means that on average the piglets showed inconsistent faeces during $1.6 \mathrm{~d}$. Of the piglets dissected on day 10 , four piglets showed no days of inconsistent faeces, seven piglets showed inconsistent faeces during $1 \mathrm{~d}$, three piglets during $2 \mathrm{~d}$, two piglets during $3 \mathrm{~d}$, one piglet during $4 \mathrm{~d}$ and one piglet during $6 \mathrm{~d}$. Only four piglets showed during $1 \mathrm{~d}$ a faecal score of 3 ; two of those piglets received the lactose diet, one the glucose and one the starch diet. For the piglets either dissected on day 3 or 10 post-weaning, two piglets showed less consistent faeces on or $1 \mathrm{~d}$ before the day of dissection.

Dietary treatment did not affect the empty BW nor organ weights, small-intestinal length or mucosal weight (data not shown). For all piglets combined, Table 3 shows the effect of post-weaning time on organ weights and various smallintestinal characteristics. Organ weights are expressed per $\mathrm{kg}$ empty BW. When compared with day 0 , empty BW was decreased on day 3 , but the pre-weaning level was reached again on day 10 post-weaning $(P<0 \cdot 01)$. The specific weight of the stomach increased from days 0 to 3 and then to day $10(P<0 \cdot 01)$. The specific weights of the liver, pancreas, small intestine, caecum and large intestine were higher on day 10 than on days 0 and $3(P<0 \cdot 01)$. The length of the small intestine and the weight of the small-intestinal mucosa were also higher on day 10 when compared with days 0 and 3 . However, the small-intestinal or mucosal weight expressed per $\mathrm{cm}$ and $\mathrm{cm}^{2}$ respectively, was not affected by post-weaning day.

Villus length and crypt depth were not differently affected by dietary carbohydrate source (Fig. 2). Irrespective of the type of diet, villus height decreased from day 0 to 3 and increased again between days 3 and 10 $(P<0.01)$. Between days 3 and 10 post-weaning, the group-mean increase in villus height for both the proximal and mid-small intestine was greater in piglets fed the diet with lactose than in those fed the other diets. However, at the proximal small intestine this was due to the longer villi at day 10 , but at the mid-small intestine this was due to the shorter villi at day 3 for the lactose-fed piglets. In general, villus height on day 10 was intermediate between that on days 0 and 3. Crypt depth was deeper on day 10 compared with that on days 0 and 3 $(P<0 \cdot 01)$, both at the proximal and mid-jejunum. Pearson correlation analysis indicated that the values of the proximal and mid-small intestine for either villus height or crypt depth were positively correlated $(P<0 \cdot 01)$. Villus height was neither correlated with crypt depth, nor with feed intake, growth or faeces consistency. Crypt depth at the mid-jejunum was positively correlated with feed intake $(P<0.01)$ and with growth $(P<0 \cdot 01)$, both between days 3 and 10 and between days 0 and 10 post-weaning.

Table 3. Pooled data for relative organ weights and small-intestinal morphology of piglets in relation to post-weaning days $\dagger$

(Least-square means and residual standard deviations)

\begin{tabular}{|c|c|c|c|c|c|}
\hline Day post-weaning ... & $0(n 6)$ & $3(n 18)$ & $10(n 18)$ & RSD & $P$ value \\
\hline EBW (kg) & $7 \cdot 3^{\mathrm{a}}$ & $6 \cdot 9^{b}$ & $7 \cdot 5^{\mathrm{a}}$ & 7.95 & ** \\
\hline Liver (g/kg EBW) & $29 \cdot 0^{\mathrm{b}}$ & $28 \cdot 4^{\mathrm{b}}$ & $32 \cdot 8^{a}$ & $3 \cdot 15$ & ** \\
\hline Pancreas (g/kg EBW) & $1.5^{\mathrm{b}}$ & $1 \cdot 7^{\mathrm{b}}$ & $2 \cdot 8^{a}$ & 0.50 & ** \\
\hline Stomach (g/kg EBW) & $5 \cdot 0^{c}$ & $6 \cdot 4^{\mathrm{b}}$ & $10 \cdot 5^{a}$ & $1 \cdot 27$ & \\
\hline Small intestine ( $\mathrm{g} / \mathrm{kg}$ EBW) & $31 \cdot 2^{b}$ & $31 \cdot 2^{\mathrm{b}}$ & $47 \cdot 2^{\mathrm{a}}$ & $6 \cdot 25$ & ** \\
\hline Length $(\mathrm{cm})$ & $736^{b}$ & $759^{b}$ & $847^{a}$ & $59 \cdot 95$ & ** \\
\hline Weight/length ( $\mathrm{g} / \mathrm{cm})$ & 0.3 & 0.3 & 0.4 & 0.04 & NS \\
\hline Mucosa $(\mathrm{g})$ & $1 \cdot 4^{b}$ & $1 \cdot 5^{\mathrm{b}}$ & $1.8^{\mathrm{a}}$ & 0.34 & $* \star$ \\
\hline Mucosa weight/surface $\left(\mathrm{g} / \mathrm{cm}^{2}\right)$ & 0.05 & 0.06 & 0.06 & 0.016 & NS \\
\hline Villus length, proximal $(\mu \mathrm{m})$ & $394^{\mathrm{a}}$ & $275^{c}$ & $324^{\mathrm{b}}$ & 77.5 & $\star \star$ \\
\hline Villus length, mid $(\mu \mathrm{m})$ & $337^{a}$ & $229^{b}$ & $303^{a}$ & $76 \cdot 7$ & ** \\
\hline Crypt depth, proximal ( $\mu \mathrm{m})$ & $166^{a}$ & $183^{\mathrm{a}}$ & $289^{b}$ & $34 \cdot 1$ & ** \\
\hline Crypt depth, mid $(\mu \mathrm{m})$ & $157^{a}$ & $181^{a}$ & $254^{\mathrm{b}}$ & $36 \cdot 8$ & ** \\
\hline Caecum (g/kg EBW) & $1.5^{\mathrm{b}}$ & $1 \cdot 7^{\mathrm{b}}$ & $2 \cdot 0^{\mathrm{a}}$ & 0.41 & $* *$ \\
\hline Large intestine ( $\mathrm{g} / \mathrm{kg}$ EBW) & $11.5^{\mathrm{b}}$ & $12 \cdot 8^{b}$ & $19 \cdot 1^{\mathrm{a}}$ & 3.05 & $\star \star$ \\
\hline
\end{tabular}

EBW, empty body weight.

$a, b, c$ Least square means with unlike superscript letters were significantly different $(P<0.01)$.

The day of post-weaning had a significant influence: ${ }^{\star \star} P<0.01$.

†For details of procedures, see p. 907. 
(A)

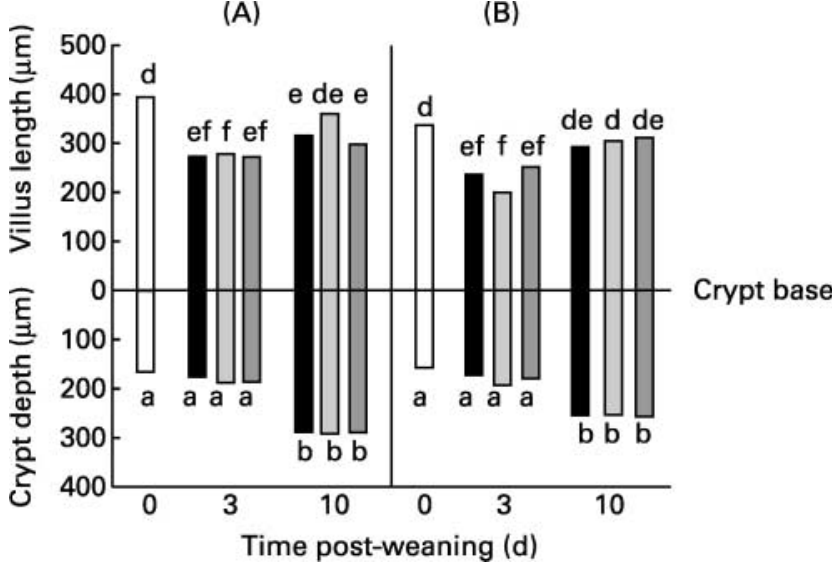

Fig. 2. Villus height and crypt depth at the proximal small intestine (A) and mid-small intestine (B) of piglets fed either the glucose (ם), lactose $(\square$ ) or starch $(\square)$ diet. Data are given for 0,3 and $10 \mathrm{~d}$ postweaning. Values are least-square means; values for residual standard deviation are: proximal villus height, $79.7 \mu \mathrm{m}$; mid-villus height, $79.3 \mu \mathrm{m}$; proximal crypt depth, $35.8 \mu \mathrm{m}$; mid-crypt depth, $38.3 \mu \mathrm{m}$ $(n 6)$. For each site, for both villus length and crypt depth, statistical comparisons were made between diets within days and between days for the same diet. There were no effects of the type of dietary carbohydrate within day 3 or 10 . Post-weaning day had significant effects: ${ }^{\mathrm{a}, \mathrm{b}, \mathrm{c}} P<0.05 ;{ }^{\mathrm{d}, \mathrm{e}, \mathrm{f}} 0.10>P>0.05$.

However at the proximal jejunum crypt depth was not correlated with feed intake and growth. Crypt depths at the proximal and mid-jejunum were positively correlated with the specific weight of the proximal, mid- and distal small intestine $(P<0 \cdot 01)$. Villus height was not correlated with the specific weights of the small intestine.

Table 4 shows the $\mathrm{pH}$ of the chyme at different sites of the gastrointestinal tract. Diet composition did not affect the $\mathrm{pH}$. In the stomach and proximal small intestine, the $\mathrm{pH}$ of the contents was not affected by the time since weaning. However, further along the gastrointestinal tract, $\mathrm{pH}$ was decreased on day 10 compared with days 0 and 3. The $\mathrm{pH}$ was not correlated with feed intake, growth and villus length. For the mid- and distal small intestine, caecum and large intestine, the $\mathrm{pH}$ of the contents was negatively correlated with crypt depth and the specific weight of the small intestine.
Hp levels in plasma were not affected by diet composition (Fig. 3). On day 10 post-weaning, Hp levels were increased $(P<0.05)$ when compared with those on either day 0 or 3 . Hp levels were not correlated with feed intake, growth and villus height $(P>0 \cdot 10)$, but were positively correlated with crypt depth $(P<0 \cdot 05)$.

\section{Discussion}

It has been shown that feed intake is positively correlated with villus height (Kelly et al. 1991; Pluske et al. 1996; Verdonk et al. 2001a). To study the effect of carbohydrate source on small-intestinal architecture independently of feed intake, the piglets were offered a predetermined maximum amount of feed. However, the differences in daily feed intakes between the piglets were still substantial, with an average $\mathrm{CV} / \mathrm{d}$ of $44 \%$. Nevertheless, feed intake did not differ between the dietary treatments. Likewise, average daily gain and feed efficiency were not affected by the carbohydrate source in the diet. Earlier growth performance trials (Jin et al. 1998; Lee et al. 2000; Mavromichalis et al. 2001) with piglets weaned at 3 weeks of age and fed ad libitum showed that dextrin, molasses, and mono- and disaccharides were utilised equally efficiently. However, these carbohydrates induced higher feed intake and better growth performance than did starch. DM digestibility was neither affected by carbohydrate source (Lee et al. 2000; Mavromichalis et al. 2001) nor was decreased by the use of starch (Jin et al. 1998). Veum \& Mateo (1986) found similar growth performance for piglets weaned at $1 \mathrm{~d}$ of age and fed a liquid diet containing either $53 \%$ glucose, lactose, sucrose, or maize starch.

The observed decrease in villus length after weaning followed by partial recovery within $10 \mathrm{~d}$ post-weaning is in agreement with the results of others (Nabuurs et al. 1993; Van Beers-Schreurs, 1996; Van Dijk, 2001; Verdonk et al. 2001 b). It was hypothesised that lactose in the weaner diet would preserve villus length. However, the results show that villus length was not affected by the carbohydrate source. Villus length at the proximal small intestine of the piglets receiving the diet with lactose seemed to recover somewhat faster than that of the piglets receiving the diets containing either glucose or starch. However,

Table 4. Effect of diet composition and day post-weaning on $\mathrm{pH}$ of the chyme at different sites in the gastrointestinal tract $†$ (Least-square means and residual standard deviations)

\begin{tabular}{|c|c|c|c|c|c|c|c|c|c|}
\hline & \multicolumn{4}{|c|}{ Dietary variable } & \multicolumn{5}{|c|}{ Day post-weaning } \\
\hline & Glucose (n 12) & Lactose (n 12) & Starch $(n 12)$ & RSD & $0(n 6)$ & $3(n 18)$ & $10(n 18)$ & $\mathrm{RSD}$ & $P$ value \\
\hline Stomach & $4 \cdot 5$ & $4 \cdot 2$ & $4 \cdot 4$ & 0.76 & $4 \cdot 7$ & $4 \cdot 2$ & $4 \cdot 6$ & 0.80 & NS \\
\hline Proximal SI & $5 \cdot 7$ & $6 \cdot 0$ & $5 \cdot 8$ & 0.44 & 5.9 & $6 \cdot 0$ & $5 \cdot 7$ & 0.42 & NS \\
\hline Mid-SI & $6 \cdot 4$ & $6 \cdot 4$ & $6 \cdot 3$ & 0.33 & $6 \cdot 5^{\mathrm{ab}}$ & $6 \cdot 5^{\mathrm{a}}$ & $6 \cdot 3^{b}$ & 0.32 & * \\
\hline Distal SI & 6.7 & $6 \cdot 8$ & $6 \cdot 8$ & 0.57 & $7 \cdot 2^{a}$ & $7 \cdot 0^{a}$ & $6 \cdot 5^{\mathrm{b}}$ & 0.51 & ** \\
\hline Caecum & 5.9 & 5.9 & $6 \cdot 2$ & 0.49 & $6 \cdot 6^{a}$ & $6 \cdot 2^{b}$ & $5 \cdot 8^{c}$ & 0.46 & $\star \star *$ \\
\hline
\end{tabular}

SI, small intestine.

a,b,c Least square means within a row, for day post-weaning, with unlike superscript letters were significantly different.

The day of post-weaning had a significant influence: ${ }^{\star} 0 \cdot 05<P<0.10$ (tendency), ${ }^{\star \star} P<0.01$. Diet composition did not significantly affect the $\mathrm{pH}$ of chyme at different sites. The repeated measures procedure of the general linear model indicated an effect of site $(P<0 \cdot 01)$ and an interaction between site and day of dissection $(P<0.01)$.

†For details of diets and procedures, see Tables 1 and 2 and p. 907. 

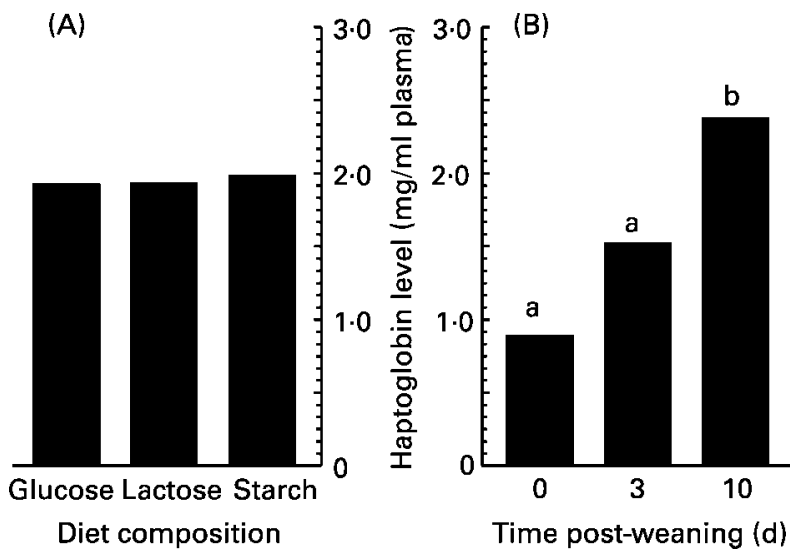

Fig. 3. Haptoglobin levels on days 0,3 and 10 post-weaning in plasma of piglets fed either the glucose, lactose or starch diet. (A), residual standard deviation $(R S D)=1 \cdot 2 ; n 12$ for days 3 and 10 post-weaning combined. (B), RSD $=1.1 ; n 6$ on day $0, n 18$ on days 3 and 10 . Values are least-square means. ${ }^{a, b}$ Values with unlike letters were significantly different $(P<0.05)$.

the apparent lactose effect was mainly due to one piglet with a villus length of $535 \mu \mathrm{m}$ on day 10 post-weaning, while villus height of the other five piglets of that experimental group ranged between 236 and $365 \mu \mathrm{m}$. Therefore, it may be concluded that lactose has no specific effect on villus architecture.

The present study showed an incidence of diarrhoea of $16 \%$, which is lower than the reported incidences of diarrhoea of $39 \%$ from weaning to $14 \mathrm{~d}$ post-weaning (Hampson, 1986) and $40 \%$ during the first, 69\% during the second and $50 \%$ during the third week post-weaning of piglets reared under commercial conditions (Nabuurs, 1991). Due to the low incidence of diarrhoea, no relationship was observed between faeces consistency and villus architecture.

Easily fermentable dietary substrates such as lactose and sucrose, but not starch, are thought to induce a favourable $\mathrm{pH}$ for digestion (Ewing \& Cole, 1994). However, the $\mathrm{pH}$ in the contents of the gastrointestinal tract at the various sites was not affected by the carbohydrate source in the diet, which agrees with the work of Ly (1992). The optimal $\mathrm{pH}$ for pepsin action is 2 and for trypsin and chymotrypsin it is 8 (Whitaker, 1994). However, most piglets did not reach these $\mathrm{pH}$ values in the stomach and proximal small intestine respectively. It seems that the $\mathrm{pH}$ values did not allow optimum digestion. The values found in the present study agree with the data of Makkink (1993). However, the $\mathrm{pH}$ values were measured in the total, mixed chyme of each segment. Kamphues (1987) reported that the $\mathrm{pH}$ of digesta close to the gastric wall or at the pyloric site is higher than in other parts of the stomach. Therefore, the above-mentioned conclusion as to discrepancies between measured and optimum values requires caution.

The $\mathrm{pH}$ in the caecum and large intestine decreased with time post-weaning. Van Beers-Schreurs (1996) showed that volatile fatty acid production in the large intestine, including that of butyric acid, increased during the first week post-weaning. With increased production of volatile fatty acids, $\mathrm{pH}$ decreases. In ileally fistulated rats, the infusion of propionic, butyric and acetic acids at physiological doses into the fistula was found to increase the crypt cell production rate of both small and large intestine in a dose-dependent manner (Sakata, 1987). Thus, a decrease in $\mathrm{pH}$ might be due to volatile fatty acids which also increase the proliferation of crypt cells and thereby increase mucosal weight. This reasoning may explain the observed negative correlation between $\mathrm{pH}$ and either crypt depth or mucosal weight.

The acute-phase response to infection, inflammation or trauma is mediated by a combination of cytokines and is associated with increased concentrations of plasma proteins produced by the liver, i.e. the acute-phase proteins (Gruys et al. 1999). Hp is a major acute-phase protein in the pig (Eckersall et al. 1996). Hp levels in the blood were not affected by diet composition. Likewise, Hiss (2001) found no effect of diet composition on Hp levels after a lipopolysaccharide injection; different levels of yeast $\beta$-glucans did not ameliorate the inflammatory response. It has been suggested that the level of $\mathrm{Hp}$ in the blood might be used as a tool to evaluate the general health status and consequently the growth performance on a farm (Knura et al. 2000). The present study found that the weaning transition increased the level of $\mathrm{Hp}$ in the blood.

In conclusion, the present experiment rejects our hypothesis that dietary lactose, when compared with glucose and starch, is beneficial for the weaning-induced compromise in small-intestinal integrity. It should be noted that the hypothesis was tested under conditions of unaltered feed intake and that the piglets used were kept under low infection pressure.

\section{Implications}

The formulation of diets for weanling piglets aims at reducing the weaning-induced decrease in gut integrity. There was suggestive evidence that lactose could have a positive effect on villus height and crypt depth. However, the present study shows that lactose, glucose and starch had no differential effect on villus architecture. It should be noted that a specific feeding regimen was used so that the experimental diets would not induce differences in feed intake. For all piglets combined, feed intake and growth were positively correlated. The present study corroborates earlier work in that feed intake rather than digestible carbohydrate composition determines post-weaning growth performance and mucosal integrity in piglets.

\section{Acknowledgements}

The authors are grateful to Dr J. Meijer and Dr C. Smits (Nutreco B.V., The Netherlands) and Dr G. Bakker (ID TNO Animal Nutrition, The Netherlands) for their helpful discussions and useful suggestions.

\section{References}

Bruininx EMAM (2002) Individually measured feed intake characteristics in group-housed weanling pigs. $\mathrm{PhD}$ thesis, University of Utrecht, The Netherlands. 
Centraal Veevoederbureau (2000) Chemical Composition, Digestibility and Feeding Value of Feedstuffs (in Dutch). Lelystad, The Netherlands: Centraal Veevoederbureau.

Darragh AJ \& Moughan PJ (1998) The composition of colostrums and milk. In The Lactating Sow, pp. 3-21 [MWA Verstegen, PJ Moughan and JW Schram, editors]. Wageningen, The Netherlands: Wageningen Pers.

Eckersall PD, Saini PK \& McComb C (1996) The acute phase response of acid soluble glycoprotein, $\alpha_{1}$-acid glucoprotein, ceruloplasmin, haptoglobin and C-reactive protein, in the pig. Vet Immunol Immunopathol 51, 377-385.

Ewing WN \& Cole DJA (1994) The Living Gut. Dungannon, UK: Context Publications.

Gruys E, Toussaint MJM, Landman WJM, Tivapasi M, Chamanza R \& van Veen L (1999) Infection, inflammation and stress inhibit growth. Mechanisms and non-specific assessment of the processes by acute phase proteins. In Production Diseases in Farm Animals, Proceedings of the 10th International Conference, pp. 72-84 [Th Wensing, editor]. Wageningen, The Netherlands: Wageningen Pers.

Hampson DJ (1986) Attempts to modify changes in the piglet small intestine after weaning. Res Vet Sci 40, 313-317.

Hiss S (2001) Entwicklung und Validierung von enzyimmunologischen Messverfahren zur Bestimmung von Haptoglobin bei verschiedenen Haustierspezies und erste Anwendungen in Pilotstudien (in German). PhD thesis, Hannover, Germany.

Hiss S, Hennies M, Gymnich S, Petersen B \& Sauerwein H (2001) Haptoglobin in pigs: development and validation of an enzyme immunoassay for various body fluids and establishment of physiological reference levels. In Production Diseases in Farm Animals, Proceedings of the 11th International Conference, p. 61 [JF Agger, editor]. Frederiksberg, Denmark: Royal Veterinary and Agricultural University.

Jin CF, Kim JH, Moon HK, Cho WT, Han YK \& Han IK (1998) Effects of various carbohydrate sources on the growth performance and nutrient utilization in pigs weaned at 21 days of age. Asian-Australas J Anim Sci 11, 285-292.

Kamphues J (1987) Untersuchungen zu Verdauungsvorgängen bei Absetzferkeln in Abhängigkeit von Futtermenge und -zubereitung sowie van Futterzusätzen (In German). PhD thesis, Tierärztliche Hochschule Hannover, Germany.

Kelly D, Smyth JA \& McCracken KJ (1991) Digestive development of the early weaned pig; effect of level of food intake on digestive enzyme activity during the immediate post-weaning period. Br J Nutr 65, 181-188.

Knura S, Lipperheide C, Petersen B \& Wendt M (2000) Impact of hygienic environment on haptoglobin concentration in pigs. In Proceedings of the 10th International Congress of Animal Hygiene, pp. 537-541 [MJM Tielen and MTh Voets, editors]. Maastricht, The Netherlands: International Society of Animal Hygiene.

Lee CH, Han YK, Lee KU, et al. (2000) Study on the nutritive value of dextrin as a carbohydrate source for pigs weaned at 21 days of age. J Anim Feed Sci 9, 647-663.

Leibbrandt VD, Ewan RC, Speer VC \& Zimmerman DR (1975) Effect of weaning and age at weaning on baby pig performance. J Anim Sci 40, 1077-1080.

Ly J (1992) Studies of the digestibility of pigs fed dietary sucrose, fructose or glucose. Arch Anim Nutr 42, 1-9.

Makkink CA (1993) Of piglets, dietary proteins and pancreatic proteases. PhD thesis, University of Wageningen, The Netherlands.

Mallet RT, Jackson MJ \& Kelleher JK (1986) Jejunal epithelial glucose metabolism: effects of $\mathrm{Na}^{+}$replacement. Am J Physiol 251, C191-C198.

Mavromichalis I, Hancock JD, Hines RH, Senne BW \& Cao H (2001) Lactose, sucrose, and molasses in simple and complex diets for nursery pigs. Anim Feed Sci Technol $\mathbf{9 3}$ 127-135.

Nabuurs MJA (1991) Etiologic and pathogenic studies on postweaning diarrhea. PhD thesis, University of Utrecht, The Netherlands.

Nabuurs MJA, Hoogendoorn A, van der Molen EJ \& van Osta ALM (1993) Villus height and crypt dept in weaned and unweaned pigs, reared under various circumstances in the Netherlands. Res Vet Sci 55, 78-84.

National Research Council (1998) Nutrient Requirements of Swine, 10th ed. Washington, DC: National Academy Press.

Okai DB, Aherne FX \& Hardin RT (1976) Effects of creep and starter composition on feed intake and performance of young pigs. Can J Anim Sci 56, 573-586.

Pluske JR, Williams IH \& Aherne FX (1996) Villous height and crypt depth in piglets in response to increases in the intake of cows' milk after weaning. Anim Sci 62, 145-158.

Sakata T (1987) Stimulatory effect of short-chain fatty acids on epithelial cell proliferation in the rat intestine: a possible explanation for trophic effects of fermentable fibre, gut microbes and luminal trophic factors. Br J Nutr 58, 95-103.

Spreeuwenberg MAM, Verdonk JMAJ, Gaskins HR \& Verstegen MWA (2001) Small intestine epithelial barrier function is compromised in pigs with low feed intake at weaning. J Nutr 131, $1520-1527$.

Spreeuwenberg MAM, Verdonk JMAJ, Verstegen MWA \& Beynen AC (2002) The effect of carbohydrate source on intestinal morphology of weaned pigs. J Anim Sci 80, Suppl. 1, 152.

Van Beers-Schreurs H (1996) The changes in the function of the large intestine of weaned pigs. PhD thesis, University of Utrecht, The Netherlands.

Van Dijk A (2001) Spray-dried animal plasma in the diet of weanling piglets: influence on growth performance and underlying mechanisms. $\mathrm{PhD}$ thesis, University of Utrecht, The Netherlands.

Verdonk JMAJ, Spreeuwenberg MAM, Bakker GCM \& Verstegen MWA (2001a) Nutrient intake level affects histology and permeability of the small intestine in newly weaned piglets. In Digestive Physiology of Pigs, pp. 332-334 [JE Lindberg and B Ogle, editors]. Wallingford, UK: CABI Publishing.

Verdonk JMAJ, Spreeuwenberg MAM, Bakker GCM \& Verstegen MWA (2001b) Effect of protein source and feed intake level on the small intestine in newly weaned piglets. In Digestive Physiology of Pigs, pp. 347-349 [JE Lindberg and B Ogle, editors]. Wallingford, UK: CABI Publishing.

Veum TL \& Mateo JP (1986) A review of the utilization of lactose, glucose, sucrose and cornstarch by neonatal piglets reared artificially. In Swine in Biomedical Research, pp. 735-743 [ME Tumbleson, editor]. New York: Plenum Press.

Weurding RE, Veldman A, Veen WAG, van der Aar PJ \& Verstegen MWA (2001) In vitro starch digestion correlates well with rate and extent of starch digestion in broiler chickens. J Nutr 131, 2336-2342.

Whitaker JR (1994) Principles of Enzymology for the Food Sciences, 2nd ed., pp. 273-300 New York: Marcel Dekker Inc. 